\title{
斜張橋のシステムダンピングに関する 2,3 の考察 SYSTEM DAMPING OF CABLE-STAYED GIRDER BRIDGES
}

\author{
前田幸 雄* ・前 田 研 一**. 越 後 滋*** \\ By Yukio MAEDA, Ken-ichi MAEDA and Shigeru ECHIGO
}

\section{1. 緒}

\section{言}

近年, 斜張橋は急速な発展を遂げ, 主径間長 $200 \sim 400$ $\mathrm{m}$ 程度の橋梁に適した型式として定着しつつあり, さら に長径間の橋梁においても従来の吊橋より優れた型式で あるとさえ，いわれ始めている11,2). そして，わが国に おいても, 主径間長 $400 \mathrm{~m}$ 級の長大斜張橋の建設ある いは計画が推進されている3),4). こうした斜張橋の発展 は, 大型高速電算機の普及に伴う解析理論, 数值計算技 法の進歩などに負うところが大きい. しかしながら，斜 張橋の歴史はまだ浅く, 比較的新しい構造型式の橋梁で あるといえ, 特に動的応答性状の研究などには幾つかの 問題点が残されていると思われる.

斜張橋の動的応答性状に関し，F． Leonhardt らは, 斜張橋が特有のシステムダンピング (System Damping) によって鉛值たわみ振動に対する高い動的安定性を有す ることを報告し，その要因として，

(1) ケーブルのひずみ挙動が, サグの影響により, 非 線形となる.

(2) マルチケーブル型式の場合, 多くのケーブルはお のおのに弦としての異なった固有振動周期をもつことか ら，構造全体の各モードに対応する振動を励起するよう な際にも, ケーブルの横振動の干渉により, 振幅の発達 が急速に妨げられる.

ことなどを挙げている ${ }^{5)}$. 前者の例としては, Norderelbe 橋の振動実験 ${ }^{6}$ において，ケーブルの段数が少ない にもかかわらず, $2 \mathrm{~cm}$ 程度のサグ 変化の場合にも，対 数減衰率の顕著な増加がみられたことを報告している.

また，後者の例としては，Zárate-Brazo Largo 橋に関 する模型実験 ${ }^{7), 8)}$ において，走行列車荷重に対する高い

* 正会員 工博 大阪大学教授 工学部士木工学科

** 正会員 工修 川田工業 (株) 技術本部研究室

*** 正会員 工修川田工業 (株) 技術本部研究室
減衰性が認められたこと，および，Pasco-Kennewick 橋の張出し架設途中 ${ }^{9}$ において, 暴風時にも有害な振動 が観測されなかったことなどを報告している.

したがって, 長大斜張橋の動的応答性状を論ずる場合 には，このシステムダンピングの効果を無視できないこ とは明らかである.しかしながら，特に後者の要因につ いては推測の域を出ていないことから, 今後の研究を待 つ必要があり, 一方において, 他に支配的な要因が存在 寸ることも十分に考えられ，この方向からの研究も急務 であると思われる. そして, F. Leonhardt らも指摘し ていることであるが, 多くの斜張橋において実測されて いる振幅の大きいケーブル振動とも関連させて，検証す る必要があると思われる.

ところで，わが国における斜張橋の動的応答性状に関 する代表的な研究としては，小松・川谷の論文 ${ }^{10)}$ があ り, 各種の型式を対象にして L-20 (道路橋示方書) 相 当設計荷重列走行による動的増幅率の值を算定し, 多く の重要な成果を報告している. そして, その導入部にお いて, 3 段ケーブル斜張橋の計画案を対象に, 弦として の横振動の一次固有振動数が構造全体の対称一次の固有 振動数と近接するように全段のケーブル張力を調整する ことによって，単一集中荷重走行による動的増幅率が顕 著に低減されるという一計算結果を与え, ケーブルがダ ンパーの役割を果たしたことによるものであるとしてい る（ただし，観点が異なっていたことから，それ以上の 考察は行っていない).

また，高久ら ${ }^{11)}$ は, 実橋の加振実験において，ヶーブ ルの共振により主桁の応答が正常な共振曲線を示さなか ったことを報告し，ケーブルのシステムダンピング効果 によるものであるとしている. さらに，樋上・佐々末 ${ }^{12)}$ は, 同様に実橋の加振実験において, 低振幅にしか加振 できなかったこと，および，加振停止後に主桁の応答が 急激に減衰して，それ以後はケーブルとのエネルギーの やり取りによる小さな振動が長く続く現象がみられたこ 
とを報告し，主桁とケーブルの動的相互作用によって与 えられるケーブルの抑振効果によるものであるとしてい る.

しかしながら，それらの結果は部分構造系の内部共振 によるものであると考えられ，少数段ケーブル斜張橋の 場合には困難であるが, マルチケーブル型式の場合に一 部のケーブルがそのような条件を満足することは十分に 可能であることから，その現象をさらに追究すれば，シ ステムダンピングの支配的な要因の一つとして新たに定 義し得るものであると思われる. さらに，マルチケーブ ル型式斜張橋の場合には, 設計時に特定のケーブルに対 してそのような条件を強制的に満足させることが必ずし も困難ではなく，経済的な設計を行う立場からも無視で きなくなり得るものであると思われる.

なお,このような問題の場合，ヶーブルの弦としての 横振動はケーブル張力の変化に大きく左右されると考え られ，幾何学的非線形性を考慮した動的応答解析も必要 であると思われるが，著者らは，有限変位理論に基づく 推定割線剛性行列を用いた効率的な計算手法をすでに提 案 ${ }^{13), 14)}$ している. また，特有の非線形性を考慮した斜 張橋解析への有限変位理論の適用方法についても, すで

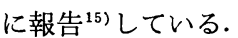

これらの議論から, 本文では, 最初に, 部分構造系と してのケーブルと主桁の振動の内部共振に起因する固有 振動特性および走行荷重時, 残留自由振動時の動的応答 特性に着目し，斜張橋のシステムダンピングの支配的な 一要因を新たに定義する．次には，斜張橋に擬した簡単 な計算モデルに対する種々の数值計算結果から，定義の 妥当性を検討する. さらに，実橋試験を行い，定義した 要因によるシステムダンピングが，実橋において実際に 生じることを確認する. そして，最後には，マルチケー ブル型式の長大斜張橋の実橋設計例を対象として, L-20 相当設計荷重列走行による動的応答の線形化解析および 非線形解析を実行し，システムダンピングに関する若干 の設計資料を得ることを試みる.

\section{2. システムダンピングの要因の定義}

\section{（1） 部分構造系の内部共振}

部分構造の固有円振動数が互いに近接する場合, 内部 共振（外力の振動数が近接する場合の通常のものではな い）を起こし，全体構造としてはおのおのの相似な振動 成分が異なる比率で連成する 2 種の固有振動モードを生 じることが知られている.

著者ら ${ }^{16)}$ は，斜張橋のようにケーブルおよび主桁が異 質な部分構造として明確に分割される構造においては内
部共振が容易に起こることを，特殊な型式に対してでは あるが理論的および実験的にすでに確認している.さら に，そのような場合の 2 種の固有振動モードにおいて は，ケーブルの横振動の振動成分が逆位相で連成するこ とを報告している.

本章では，このような内部共振に起因する固有振動特 性，および，それによる走行荷重時, 残留自由振動時の 動的応答特性に着目し，斜張橋のシステムダンピングの 支配的な一要因を新たに定義する.

\section{（2）走行荷重による動的応答}

ケーブルを鎖状ケーブル部材として取り扱うことによ って，対象とする現象は容易に解析されると思われる. 部分構造系としてのケーブルと主桁の振動の内部共振に よって生じる 2 種の固有振動モードに対応するべクトル を $\boldsymbol{y}_{i}, \boldsymbol{y}_{j}$, 近接する固有円振動数を $\omega_{i}, \omega_{j}$ とすれば,

$$
\begin{aligned}
\ddot{\Phi}_{k}(t)+\omega_{k}{ }^{2} \Phi_{k}(t)= & \left(\boldsymbol{y}_{k}{ }^{T} \cdot \boldsymbol{M} \cdot \boldsymbol{y}_{k}\right)^{-1} \cdot\left\{\boldsymbol{y}_{k}{ }^{T} \cdot \boldsymbol{f}(t)\right\} \\
& (k=i, j) \cdots \cdots \cdots \cdots \cdots \cdots \cdots \cdots \cdots \cdots \cdots \cdots(1)
\end{aligned}
$$

なる式で, 一般化座標 $\Phi_{i}(t), \Phi_{j}(t)$ が表わされる.こ こに, $\boldsymbol{f}(t)$ は外力ベクトルであり， $\boldsymbol{M}$ は質量マトリッ クスである.

いま，説明の便宜上から単一集中荷重が主桁上を速度 $V$ で走行する場合を考え，フーリ工級数展開すれば，外 カベクトル $\boldsymbol{f}(t)$ は次式のように表わされる.

$$
\boldsymbol{f}(t)=\sum_{n=1}^{\infty}\left(\boldsymbol{a}_{n} \sin \omega_{p n} t\right), \omega_{p n}=\frac{n \pi V}{L}
$$

ここに， $a_{n}$ は定数べクトルであるが，具体的な表現は 省略する. また, $\omega_{p n}$ は正弦関数型外力の固有円振動数 に対応するものであり，Lは主桁の全長である.

式（2）を式（1）に代入すれば,

$$
\begin{array}{r}
\Phi_{k}(t)=\left(\boldsymbol{y}_{k}^{T} \cdot \boldsymbol{M} \cdot \boldsymbol{y}_{k}\right)^{-1} \cdot \sum_{n=1}^{\infty}\left\{\left(\boldsymbol{y}_{k}^{T} \cdot \boldsymbol{a}_{n}\right)\right. \\
\left.\cdot \frac{1}{\omega_{k}^{2}-\omega_{p n}{ }^{2}}\left(\sin \omega_{p n} t-\frac{\omega_{p n}}{\omega_{k}} \sin \omega_{k} t\right)\right\} \\
(k=i, j) \cdots \cdots \cdots \cdots \cdots \cdots \cdots(3)
\end{array}
$$

なる式で，一般化座標の解が得られる。

したがって，同様に説明の便宜上から，注目する変位 を主桁およびヶーブルのおのおの一箇所のものとし， $\boldsymbol{y}_{\boldsymbol{i}}$, $\boldsymbol{y}_{j}$ の対応する要素を $y_{G i}, y_{G j}$ および $y_{C i}, y_{C j}$ とすれ ば,

$$
\begin{array}{r}
Y_{G k}(t)=y_{G k} \cdot \Phi_{k}(t), \quad Y_{C_{k}}(t)=y_{C k} \cdot \Phi_{k}(t) \\
(k=i, j) \cdots \cdots \cdots \cdots \cdots \cdots
\end{array}
$$

なる式で, 動的応答值 $Y_{G i}(t), Y_{G j}(t)$ および $Y_{C i}(t)$, $Y_{C j}(t)$ は与えられる. さらに，説明をより簡単にする ために, 式 (3) において, 正弦関数型外力ベクトル $\boldsymbol{a} \sin \omega_{p} t$ に関する成分が卓越するとすれば，式 (4) は 次のように書き換えられる. 


$$
\left.\begin{array}{r}
Y_{G k}(t)=\frac{y_{G k} \cdot F_{k}}{\omega_{k}^{2}-\omega_{p}^{2}}\left(\sin \omega_{p} t-\frac{\omega_{p}}{\omega_{k}} \sin \omega_{k} t\right) \\
Y_{C_{k}}(t)=\frac{y_{C k} \cdot F_{k}}{\omega_{k}{ }^{2}-\omega_{p}^{2}}\left(\sin \omega_{p} t-\frac{\omega_{p}}{\omega_{k}} \sin \omega_{k} t\right)
\end{array}\right\}
$$

ここに,

$$
F_{k}=\left(\boldsymbol{y}_{k}{ }^{T} \cdot \boldsymbol{M} \cdot \boldsymbol{y}_{k}\right)^{-1} \cdot\left(\boldsymbol{y}_{k}{ }^{T} \cdot \boldsymbol{a}\right)
$$

であり，式（5）の第 1 項が強制振動項，および，第 2 項が自由振動項である.

\section{（3）自由振動項の beating 現象}

式（5）の自由振動項を $\bar{Y}_{G i}(t), \bar{Y}_{G j}(t)$ および $\bar{Y}_{C i}$ $(t), \bar{Y}_{C j}(t)$ で表わせば, 次式のように与えられる.

$\bar{Y}_{G k}(t)=\lambda_{k} \cdot X_{G k} \sin \omega_{k} t, \bar{Y}_{C k}(t)=\lambda_{k} \cdot X_{C_{k}} \sin \omega_{k} t$

$$
(k=i, j)
$$

ここに,

$$
\lambda_{k}=\frac{\left(\omega_{p} / \omega_{k}\right)}{1-\left(\omega_{p} / \omega_{k}\right)^{2}}
$$

であり, $X_{G i}, X_{G j}$ および $X_{C i}, X_{C j}$ は,

$$
X_{G k}=\frac{y_{G k} \cdot F_{k}}{\omega_{k}{ }^{2}}, X_{C k}=\frac{y_{C k} \cdot F_{k}}{\omega_{k}{ }^{2}}(k=i, j)
$$

なる式で示される, 静的な場合の応答振幅である.

初等の振動学 ${ }^{17}$ における特異な一現象として, 円振動 数の近接した 2 種の正弦波が起こす beating（吟り）現 象というものがあるが, 自由振動項がそのような現象を 生じることは式（7）から明らかである.

すなわち, 2 種の近接した固有円振動数 $\omega_{i}, \omega_{j}$ に対 応する, 注目した主桁の変位の自由振動項を合成して得 られる正弦波は,

$$
\left.\begin{array}{l}
\bar{Y}_{G i}(t)+\bar{Y}_{G j}(t)=\bar{A}_{G}(t) \sin \left\{\left(\omega_{i}+\frac{\delta}{2}\right) t-\Phi_{G}\right\} \\
\bar{A}_{G}(t)=\sqrt{\left(\lambda_{i} \cdot X_{G i}\right)^{2}+\left(\lambda_{j} \cdot X_{G j}\right)^{2}} \quad+2\left(\lambda_{i} \cdot X_{G i}\right)\left(\lambda_{j} \cdot X_{G j}\right) \cos \delta t \\
\phi_{G}=\tan ^{-1}\left(\frac{\lambda_{i} \cdot X_{G i}-\lambda_{j} \cdot X_{G j}}{\lambda_{i} \cdot X_{G i}+\lambda_{j} \cdot X_{G j}} \cdot \tan \frac{\delta}{2} t\right) \\
\delta=\left|\omega_{i}-\omega_{j}\right|
\end{array}\right\}
$$

なる式で現わされ, beating 現象によって, 振幅 $\bar{A}_{G}(t)$ が,

$$
\left.\begin{array}{l}
\bar{A}_{G, \max }=\left|\lambda_{i} \cdot X_{G i}+\lambda_{j} \cdot X_{G j}\right| \\
\bar{A}_{G, \min }=\left|\lambda_{i} \cdot X_{G i}-\lambda_{j} \cdot X_{G j}\right|
\end{array}\right\}
$$

なる最大, 最小值で周期 $2 \pi / \delta$ の周期関数となる.

したがって, 強制振動項の振幅および自由振動項の最 大振幅 $\bar{A}_{G, \max }$ が内部共振をほとんど起こさない場合 と差異がないならば，主桁の着目した変位の動的応答值 が最小振幅 $\bar{A}_{G, \min }$ の付近ではかなり減少することに なる（特に, 走行開始後, beating 現象の $1 / 2$ 周期付近 で動的応答の最大值が生じるならば，その効果は非常に
大きい).そして, 静的応答值には当然, 差異がないこ とから，動的増幅率がかなり低減されることになる.

また, 荷重が走行後の残留自由振動においても, 振 幅, 位相差は異なるが, 自由振動項に対応するもののみ となることから, 構造減衰注) との相互作用によって, 高 い減衰性が与えられることになる.

一方，ケーブルの注目した変位については，対応する 2 種の固有振動モードに拈いてケーブルの振動成分が前 述したように逆位相で連成するならば，静的な場合の応 答振幅 $X_{C i}, X_{C j}$ が逆符号となることから，自由振動 項の振幅 $\bar{A}_{C}(t)$ は,

$$
\left.\begin{array}{l}
\bar{A}_{C, \text { min }}=\left|\lambda_{i} \cdot X_{C i}+\lambda_{j} \cdot X_{C j}\right| \\
\bar{A}_{C, \text { max }}=\left|\lambda_{i} \cdot X_{C i}-\lambda_{j} \cdot X_{C j}\right|
\end{array}\right\}
$$

なる最小, 最大值で周期 $2 \pi / \delta$ の周期関数となる.

したがって, 逆に自由振動項の最小振幅 $\bar{A}_{C, \mathrm{~min}}$ が内 部共振をほとんど起こさない場合と差異がなければ，注 目したケーブルの変位の動的応答值が増大することにな る.

ゆえに，これらのことから，部分構造系としてのケー ブルと主桁の振動の内部共振によって生じる，おのおの の相似な振動成分が異なる比率で連成し，固有円振動数 が近接した, 2 種の固有振動モードに対応する自由振動 項の beating 現象を, 斜張橋のシステムダンピングの支 配的な一要因として新たに定義する.

\section{3. 定義の妥当性の検討}

定義したシステムダンピングの要因の妥当性を検討す るために，本章では，斜張橋に擬した簡単な計算モデル に対して, 種々の数值計算を行い, その結果について考 察する.

\section{（1）計算モデルと計算結果}

計算モデルは図一1 に示すようなものであり，ケーブ ルを鎖状ケーブルとして取り扱うモデルに加え，従来の 計算とも対応させるために，単なる軸方向力部材として 取り扱うモデルも対象とする.さらに，表一1 がその断
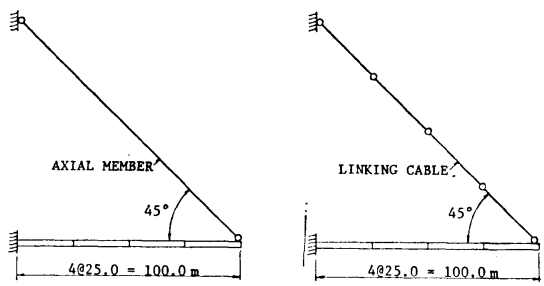

図一1計算モデル

注）粘性減衰に対応し，エネルギー逸散を伴う本来の意の減 衰を指寸. 
表一1計算モデルの断面諸量

\begin{tabular}{l|ll|c|c}
\hline & & CABLE & GIRDER \\
\hline AREA & $A$ & $\left(\mathrm{~m}^{2}\right)$ & 0.1 & 1.0 \\
INERTIA & $I$ & $\left(\mathrm{~m}^{4}\right)$ & 0.0 & 4.0 \\
Y. MODULUS & $E$ & $\left(\mathrm{t} / \mathrm{m}^{2}\right)$ & $2.0 \times 10^{7}$ & $2.1 \times 10^{7}$ \\
DEAD LOAD & $w_{d}(\mathrm{t} / \mathrm{m})$ & 1.0 & 50.0 \\
\hline
\end{tabular}

$(1.0 \mathrm{t} \fallingdotseq 9.8 \mathrm{kN})$

面諸量である.

数值計算においては，鎖状ケーブルの中間の各節点に 自重に対応する集中質量を与えるが，サグの影響を除く ために, 静的荷重としては両端の節点に集中するものと する. また，ケーブルの無応力長は，所定の完成時張力 に対応する導入引張応力 $\sigma_{t}$ が静的平衡状態で生じる条 件を，満足するように事前に算定する．一方，主桁の無 応力形状は，ヶーブルの張力および死荷重に対応する外 荷重に対して, 所定の完成形状で静的平衡状態となる条 件を，満足するように事前に算定する．ささらに，固有振 動解析は, 静的平衡状態での有限変位理論に基づく接線 剛性行列を用いて行う.

したがって, 導入引張応力 $\sigma_{t}$ の各值について数值計 算を行えば，図一2〜4 および 表一2，3 が得られる.

まず，表一2 は，計算モデルおよび導入引張応力の相

表一2 固有円振動数

$(\mathrm{rad} / \mathrm{s})$

\begin{tabular}{c|c|c|c}
\hline \multicolumn{2}{c|}{} & $\begin{array}{c}\text { AXIAL } \\
\text { MEMBER } \\
\left(\sigma_{t}=3600 \mathrm{~kg} / \mathrm{cm}^{2}\right)\end{array}$ & \multicolumn{2}{c}{ LINKING CABLE } \\
\cline { 3 - 5 }
\end{tabular}

$(1.0 \mathrm{~kg} \fallingdotseq 9.8 \mathrm{~N})$
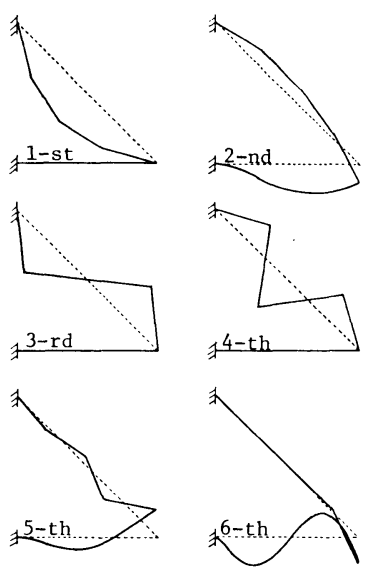

$\left(\sigma_{t}=3600 \mathrm{~kg} / \mathrm{cm}^{2}\right)$
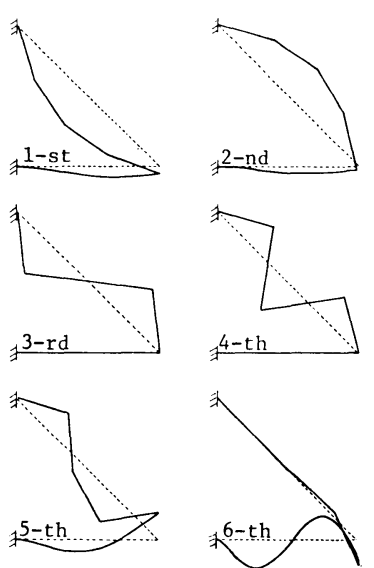

$\left(\sigma t=6300 \mathrm{~kg} / \mathrm{cm}^{2}\right)$
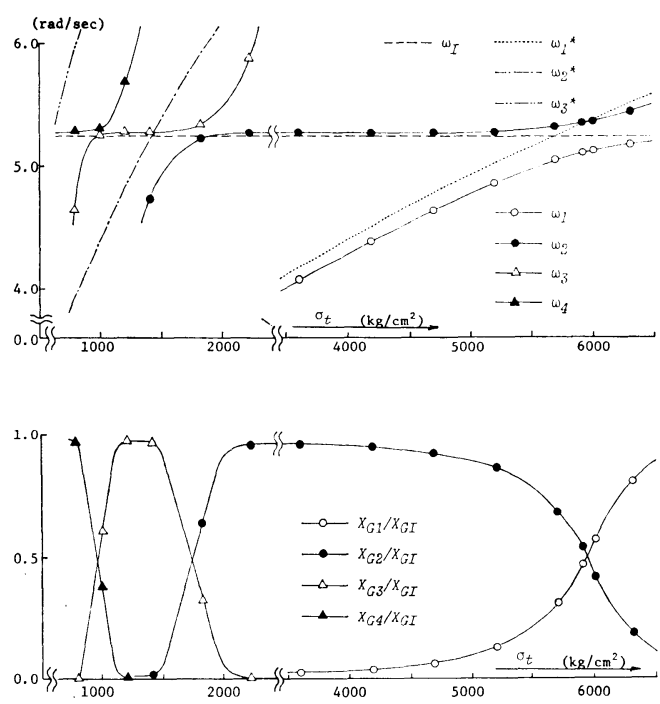

図一3 固有円振動数および静的な場合の応答振幅比

違した 3 ケースの場合の固有円振動数を示すものであ り，図一2 は，鎖状ケーブルとして取り扱ったモデルの 2 ケースの場合の固有振動モードを示すものである.

図一3 (上図) は, ケーブルを軸方向力部材として取 り扱ったモデルの主桁の 1 次振動モードに対応する固有 円振動数 $\omega_{I}$, および，鎖状ケーブルとしたモデルの 1 次 4 次の固有円振動数 $\omega_{1} \sim \omega_{4}$ の值の, 導入引張応力 $\sigma_{t}$ の変化に伴う変動状況を示すものである. この図に は，参考のために，ヶーブルの弦としての 1 次〜 3 次の 固有円振動数 $\omega_{1}{ }^{*} \sim \omega_{3} *$ の值む付記してある. また, 図 -3 (下図) は，主桁自由端に正弦関数型外力 $P \sin \omega_{p} t$ が鉛直方向に作用するとした際における, 固有円振動数 が $\omega_{1} \sim \omega_{4}$ の固有振動モードに関する主析自由端の鉛直 方向変位の静的な場合の応答振幅 $X_{G_{1}} \sim X_{G_{4}}$ と, $\omega_{I}$ に 関する $X_{G I}$ との比を示すものである.

図一4 は, 正弦関数型外力の円振動数 $\omega_{p}$ と $\omega_{I}$ との比が 0.5 の場合について, 主桁自由端の鉛直 方向変位およびケーブル中央点の法線方向変位の 強制振動項の振幅比およびその合算值を示したも のである. すなわち, $X_{C_{1}}, X_{C_{2}}$ は, 法線方向に 座標変換したケーブル中央点の静的な場合の応答 振幅である.

さらに，図一-5 は，同様に正弦関数型外力の円 振動数 $\omega_{p}$ と $\omega_{I}$ との比が 0.5 の場合について, beating 現象における, 主析自由端の鉛直方向変 位, ケーブル中央点の法線方向変位の自由振動項 の最大, 最小振幅比, および, 周期を示すもので ある。

なお, 表一3 は, ケーブルが鎖状ケーブル部材 と軸方向力部材との両者の部材から成るとして, 

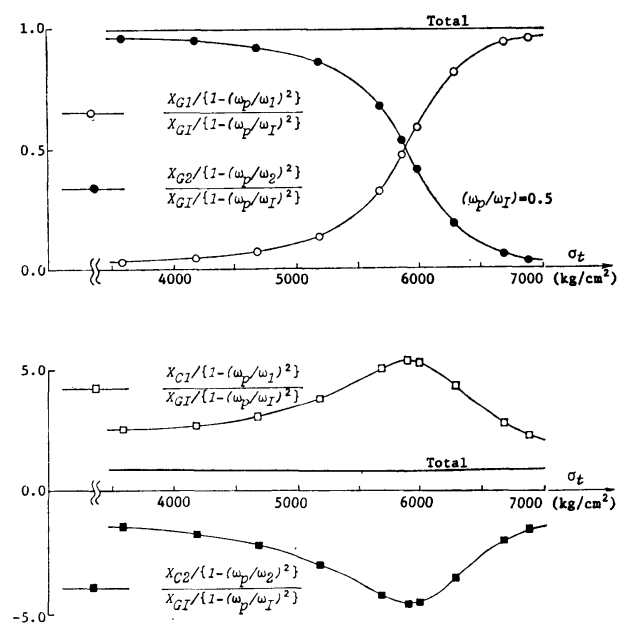

図一4強制振動項の振幅比とその合算值
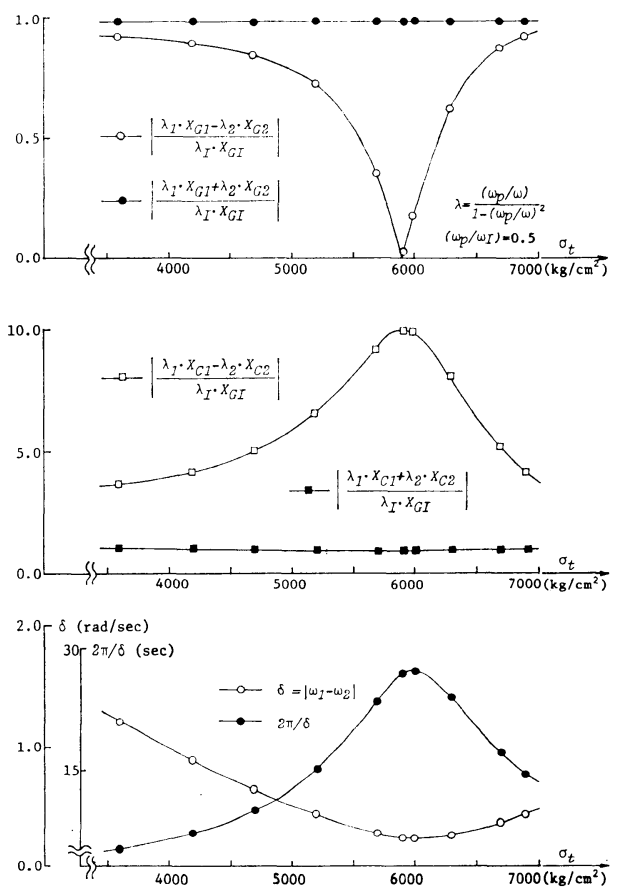

図一5 beating 現象における自由振勳項の最大, 最小振幅比および周期

鎖状ケーブル部材の断面積の全体に対する比率を 1.0 0.125 と変化させた際における, 1 次, 2 次の固有円振 動数, および, 主桁自由端の鉛直方向変位の静的な場合 の応答振幅比に及ぼす影響を表わするのである.

\section{(2) 計算結果の考察}

これらの計算結果からは, 次のようなことが考察され る.

まず，表一2 および 図一2 から，固有円振動数 $\omega_{I}$ に
表一3 鎖状ケーブルの断面積の比率変化が及ぼす影䇾

\begin{tabular}{|c|c|c|c|c|c|}
\hline $\begin{array}{c}\sigma_{t} \\
\left(\mathrm{~kg} / \mathrm{cm}^{2}\right)\end{array}$ & $\begin{array}{c}\text { RATIO } \\
\text { OF } \\
\text { AREA }\end{array}$ & $\begin{array}{c}\omega_{1} \\
(\mathrm{rad} / \mathrm{s})\end{array}$ & $\begin{array}{c}\omega_{2} \\
(\mathrm{rad} / \mathrm{s})\end{array}$ & $X_{G_{1}} / X_{G I}$ & $X_{G_{2}} / X_{G I}$ \\
\hline \multirow{4}{*}{5700} & 1.000 & 5.0458 & 5.3165 & 0.3064 & 0.6783 \\
\hline & 0.500 & 5.0739 & 5.2861 & 0.2261 & 0.7662 \\
\hline & 0.250 & 5.0916 & 5.2673 & 0.1517 & 0.8444 \\
\hline & 0.125 & 5.1021 & 5.2562 & 0.0925 & 0.9055 \\
\hline \multirow{4}{*}{5900} & 1.000 & 5.1136 & 5.3483 & 0.4792 & 0.5059 \\
\hline & 0.500 & 5.1460 & 5.3140 & 0.4390 & 0.5535 \\
\hline & 0.250 & 5.1689 & 5.2901 & 0.3916 & 0.6046 \\
\hline & 0.125 & 5.1849 & 5.2736 & 0.3350 & 0.6631 \\
\hline \multirow{4}{*}{6000} & 1.000 & 5.1383 & 5.3683 & 0.5707 & 0.4145 \\
\hline & 0.500 & 5.1708 & 5.3341 & 0.5680 & 0.4245 \\
\hline & 0.250 & 5.1941 & 5.3099 & 0.5720 & 0.4243 \\
\hline & 0.125 & 5.2106 & 5.2929 & 0.5837 & 0.4145 \\
\hline \multirow{4}{*}{6300} & 1.000 & 5.1892 & 5.4498 & 0.8003 & 0.1856 \\
\hline & 0.500 & 5.2145 & 5.4233 & 0.8535 & 0.1393 \\
\hline & 0.250 & 5.2300 & 5.4071 & 0.9036 & 0.0928 \\
\hline & 0.125 & 5.2390 & 5.3978 & 0.9424 & 0.0557 \\
\hline
\end{tabular}

ケーブルの弦としての 1 次のそれが近接するような導入 引張応力の場合, 部分構造系としてのケーブルと主析の 振動の内部共振によって, 固有円振動数 $\omega_{1}, \omega_{2}$ の值が 近接し，おのおのの相似な振動成分が異なる比率で連 成, ケーブルの振動成分の位相が逆転した，2 種の固有 振動モードが存在することを再確認できる.

図一3 からは，内部共振を起こすケーブルの弦として の振動成分が， 2 次， 3 次と高次になる場合にも，固有 円振動数 $\omega_{1} \sim \omega_{4}$ に対応するモードの中から, 主桁の振 動成分が卓越する 2 種の固有振動モードが現われ, 同様 の現象を生じることがわかる. また，高次になるに従っ て, 最も近接する際の 2 種の固有円振動数の值の差は小 さくなるが，零にはならないことがわかる.

図一4 からは，主析自由端の鉛直方向変位の強制振動 項の振幅の合算值がほぼ一定で, 内部共振をほとんど起 こさない場合と差異はなく，従来のようにケーブルを軸 方向力部材とした場合ともほぼ等しいことがわかる．ま た，ケーブル中央点の法線方向変位の強制振動項の合算 值は, 固有円振動数 $\omega_{1}, \omega_{2}$ が近接するに従って減少す る傾向がみられるが，内部共振をほとんど起こさない場 合と大きい差異がないことがわかる.

図一5 からは，beating 現象に抢ける主析自由端の鉛 直方向変位の自由振動項の最大振幅の值がほぼ一定で, 内部共振をほとんど起こさない場合と差異はなく，従来 のようにケーブルを軸方向力部材とした場合の振幅にも ほぼ等しいことがわかる. 一方, 最小振幅は, 2 種の固 有円振動数 $\omega_{1}, \omega_{2}$ が近接するに従って小さくなり, 最 も近接する際には零となることがわかる．また，ケーブ ル中央点の法線方向変位の自由振動項の最小振幅の値 は, $\omega_{1}, \omega_{2}$ が近接するに従って減少する傾向がみられる が，内部共振をほとんど起こさない場合と大きい差異が 
ないことがわかる．そして，最大振幅は主桁自由 端の最小振幅が小さくなるに従って逆に増大する ことがわかる.ささらに，主桁自由端の最小振幅が 小さくなるに従って, beating 現象の周期が長く なることもわかる.

なお，表一3 からは，鎖状ケーブルの断面積の 比率が小さくなるに伴って, 固有円振動数 $\omega_{1}, \omega_{2}$ はさらに近接する一方, 振幅比の差は大きくなる ことがわかる.このことは, 部分構造系としての ケーブルの振動エネルギー比が小さくなるに従っ て，主桁自由端の鉛直方向変位の自由振動項の最 小振幅は大きくなる傾向にあるが, beating 現象 の周期は長くなり，その現象自体はより生じやす くなることを意味している.

ゆえに，これらの考察からは，定義した要因が 斜張橋のシステムダンピングの支配的な一要因で あるとしてもよいと思われる。

\section{4. 実橋 試 験}

定義した要因によるシステムダンピングが，実橋にお いて，実際に生じることを確認するために，本章では， 単径間 PC 斜張橋を対象に実橋試験を行った結果を用い て，測定データを分析する.

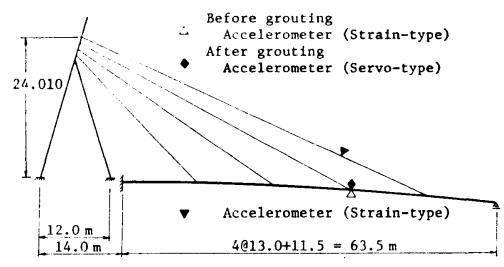

図一6 実橋試験例

表一4 実橋試験例の諸元

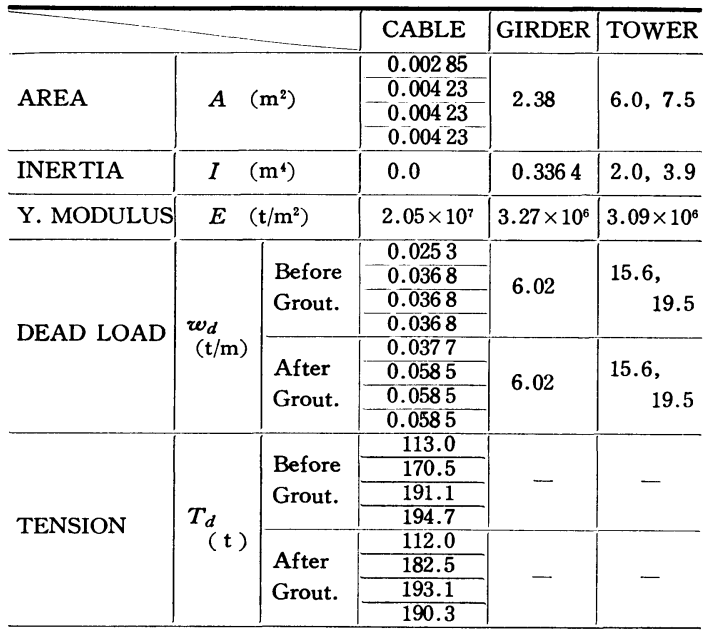

$(1.0 \mathrm{t} \doteqdot 9.8 \mathrm{kN})$

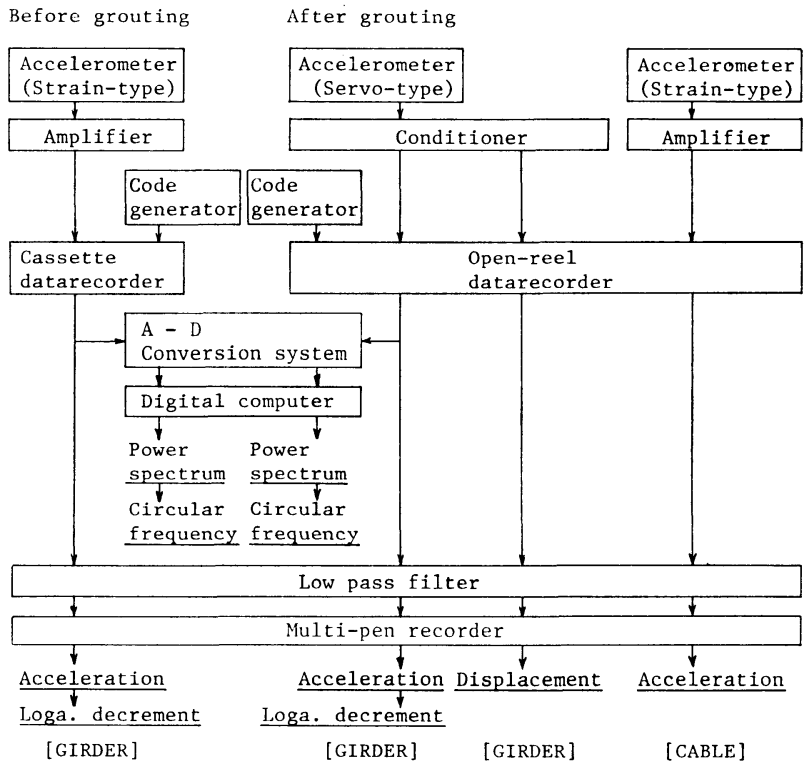

図-1 測定データの処理方法

\section{（1）試験要領之試験結果}

対象とした実橋は図一6に示すものであり，この図に 示したように, 比較のために, グラウト後の完成状態に おいてのみならず, グラウト前の状態においても, 測定 を行った. すなわち, グラウト前には, 主析測定点の鉛 直方向加速度のみを, グラウト後には, 主析測定点の鉛 直方向加速度招よびそれを電気的に変換した鉛直方向変 位, ケーブル測定点の法線方向加速度を測定項目とし た. さらに，表一4 は実橋の諸元を示すものであるが， ケーブル張力は, グラウト前およびグラウト後における 張力測定によって得られた実測值である.

試験内容としては, グラウト前には，落下試験のみ を,グラウト後には, 落下試験および走行試験を実施し た. 荷重車の重量, 落下位置および走行速度は, それぞ れ, 約 $2.0 \mathrm{t}(\fallingdotseq 19.6 \mathrm{kN})$, 支間中央および $30 \mathrm{~km} / \mathrm{h}$ であ った.

したがって, 測定されたデータを図一7に示す方法で 処理した結果, および, 考察のために行った理論計算結 果を示せば, 図一8〜11，表一5 が与えられる.なお, $\mathrm{A}-\mathrm{D}$ 変換における時間間隔は $0.02 \mathrm{~s}$ (最大周波数は 25 $\mathrm{Hz})$, データの個数は 2048 個, すなわち, データの継 続時間は $40.96 \mathrm{~s}$ (分解能は $0.024 \mathrm{~Hz}$ ) であり, パワー スペクトルはグラフィックディスプレーに描画してい る. また, 対数減衰率は, ペン書きオシログラフに描画 した記録波形から残留自由振動部の最初の 20 波の両振 幅を読み取り, 最小自乗法によって算定している.

まず, 図一8 は, グラウト前およびグラウト後の落下 試験における, 主桁測定点の鉛直方向加速度記録から得 

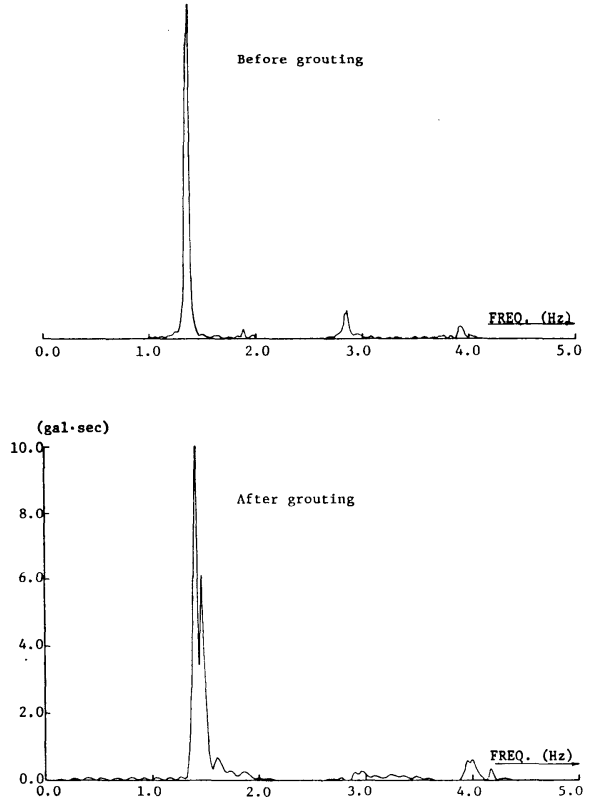

図一8 落下試験における主桁測定点のパワースペクトル

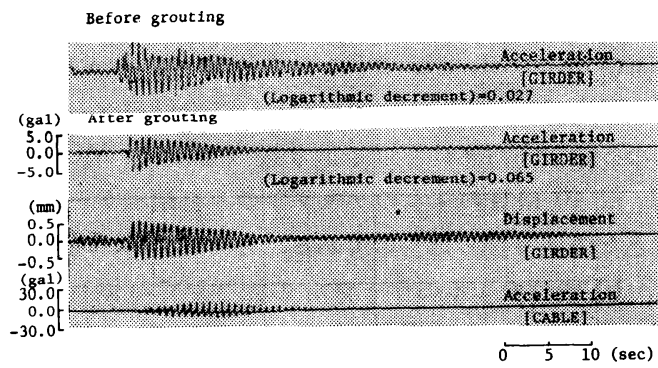

図一9 落下試験における記録波形と対数減表率

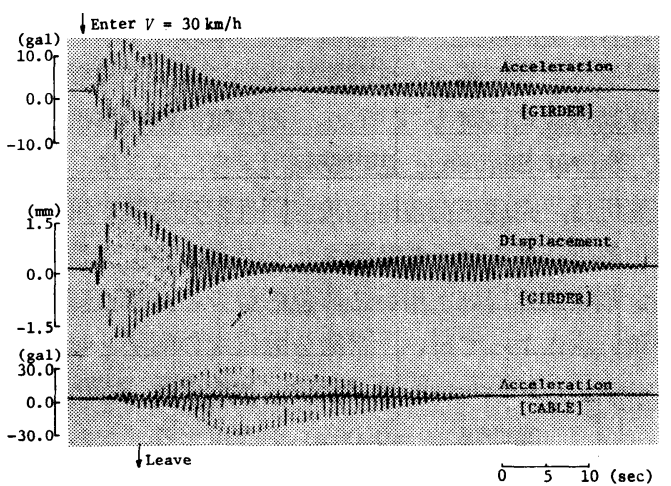

図一10 走行試験における記録波形

られたパワースペクトルを示すものであり, 図一9 は各 測定項目の記録波形，および，主标測定点の鉛直方向加 速度の記録波形から算定した対数減衰率を示すものであ る.なお，これらの図において，グラウト前の試験に関 するグラフの縦軸が不備であるのは, キャリブレーショ
表一5 固有円振動数の実測値と理論計算値

\begin{tabular}{|c|c|c|c|c|}
\hline & \multicolumn{2}{|c|}{ Before grouting } & \multicolumn{2}{|c|}{ After grouting } \\
\hline & $\begin{array}{l}\text { Experi. } \\
\text { value }\end{array}$ & $\begin{array}{r}\text { Theoreti. } \\
\text { value }\end{array}$ & $\begin{array}{l}\text { Experi. } \\
\text { value }\end{array}$ & $\begin{array}{l}\text { Theoreti. } \\
\text { value }\end{array}$ \\
\hline$\omega_{1} \quad(\mathrm{rad} / \mathrm{s})$ & 8.61 & 8.5370 & 8.92 & 8.2829 \\
\hline$\omega_{2} \quad(\mathrm{rad} / \mathrm{s})$ & 10.62 & 10.7333 & 9.17 & 8.6435 \\
\hline $\begin{aligned} \delta=\left|\omega_{1}-\omega_{2}\right| & (\mathrm{rad} / \mathrm{s})\end{aligned}$ & 2.01 & 2.1963 & 0.25 & 0.3606 \\
\hline $2 \pi / \delta \quad(s)$ & 3.13 & 2.8608 & 25.13 & 17.4243 \\
\hline
\end{tabular}

ンの記録が不良で あったことによる ものである.

また,図一10は， グラウト後の走行 試験における，各 測定項目の記録波 形を示すものであ る.

さらに，表一5 および図一11は， 全段のケーブルを 鎖状ケーブルとし て取り扱った場合 における，グラウ ト前およびグラウ 卜後の状態での 1,2 次の固有円振 動数, 固有振動モ
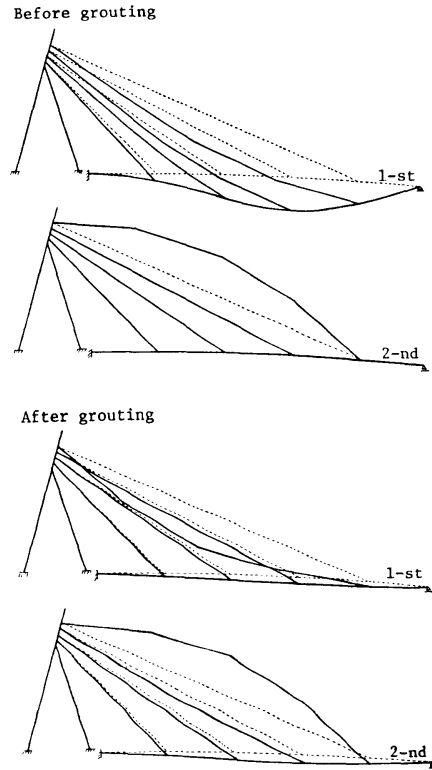

図一11固有振動モードの理論計算值 ードの理論計算結果を示すものである. なお, 表一5 に は, 参考のために, 実測值および両者のモードに対応寸 る自由振動項の beating 現象の周期も付記してある.

\section{(2) 試験結果の考察}

これらの試験結果からは，次のようなことが考察され る.

まず，図一8 および 図一9 からは，グラウト前とは異 なり，グラウト後には，内部共振によるものであると推 测される, 振動数の近接した 2 種の卓越振動モードの存 在が実測されていること, および，各測定項目の記録波 形の残留自由振動部において, beating 現象によるもの と推測される振幅の変化がみられることがわかる.ま た, グラウト前のものに比較して, グラウト後の対数減 衰率の值がかなり大きくなっていることがわかる.

図一10 からは, beating 現象によるものと推測され る振幅の変化がより明確に現われており, 荷重車通過後 の残留自由振動における主析測定点での振幅が構造減衰 も作用することによって急速に減衰していること，およ び，ケーブル測定点での振幅はそれとは逆の傾向にある 
ことがわかる.

さらに, 表一5 および 図一11 からは, 理論計算結果 においても，グラウト前とは異なり，グラウト後に，ケ 一ブル, 主枌の相似な振動成分が異なる比率で連成, ケ ーブルの振動成分の位相が逆転している. 固有円振動数 の近接した 2 種の固有振動モードが存在することがわか る. また, 固有円振動数の理論計算值が実測值とよく一 致していることもわかる.

ゆえに, これらの考察からは, 所要の条件を満足すれ ば，定義した要因によるシステムダンピングが，実橋に おいて，実際に生じ得るとしてもよいと思われる.さら に，対象とした実憍は設計において偶然に所要の条件を 満足していたものであるが，マルチケーブル型式の場合 はそのような可能性がより高いと思われ，定義した要因 は過去において実測された高い減衰性の支配的な要因の 一つであると推测される.

\section{5. マルチケーブル型式斜張橋の動的応答解析}

本章では, マルチケーブル型式斜張橋の特定のケーブ ルの完成時張力を（静的な設計から決定されるプレスト レスを他のケーブルに再配分することによって）所要の 条件を満足するように強制的に調整できる場合を想定 し, 定義した要因によるシステムダンピングの効果につ いて, 実橋設計例を対象に, 長大斜張橋の経済的な設計 を行う立場からの若干の資料を得ることを試みる.ただ し，ここでは，現象をより明確にとらえるために他のケ ーブルの横振動の振動成分を考慮しないこともあり，他 のケーブルの完成時張力の調整は行わないものとする.

対象 とする実橋設計例は 図一12 に示す中央径間長 $340 \mathrm{~m}$ のものであり， L-20 (道路橋示方書) 相当設計荷 重列が主桁上を走行する場合における動的応答解析を実 行する. この図において, 速度 $V=60 \mathrm{~km} / \mathrm{h}$ で走行する とした L-20 相当設計荷重列における $\omega_{I}$ は, 従来の解 析に対応して全段のケーブルを軸方向力部材として取り 扱う場合に得られる最低次の固有円振動数であり, $l$ は 動的外力としての P 1, P 2 の共振車頭間隔を表わして いる.

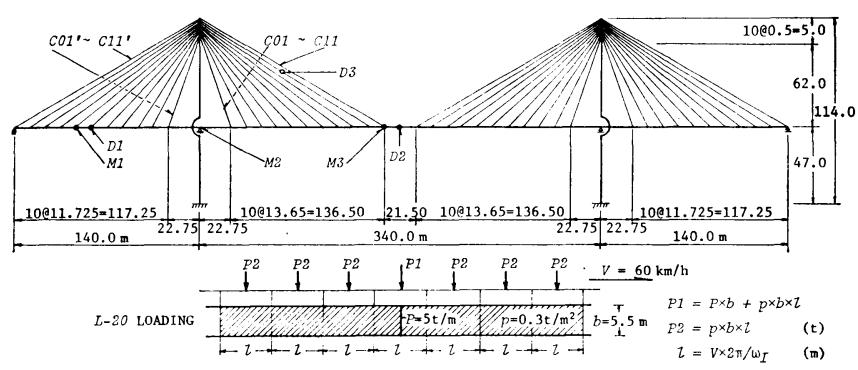

図一12 実橋設計例および L-20 相当設計荷重列
表一6 実橋設計例の諸元

\begin{tabular}{l|c|c|c|c}
\hline & CABLE & GIRDER & TOWER \\
\hline AREA & $A\left(\mathrm{~m}^{2}\right)$ & $\begin{array}{c}0.0128 \\
\sim 0.0192\end{array}$ & 1.214 & $\begin{array}{r}0.968, \\
1.392\end{array}$ \\
\hline INERTIA & $I\left(\mathrm{~m}^{4}\right)$ & 0.0 & 2.98 & $\begin{array}{r}1.518, \\
2.284\end{array}$ \\
\hline Y. MODULUS & $E\left(\mathrm{t} / \mathrm{m}^{2}\right)$ & $2.05 \times 10^{7}$ & $2.10 \times 10^{7}$ & $2.10 \times 10^{7}$ \\
\hline DEAD LOAD & $w_{d}(\mathrm{t} / \mathrm{m})$ & $\begin{array}{c}0.1408 \\
\sim 0.2112\end{array}$ & 21.6 & $9.40,13.7$ \\
\hline TENSION & $T_{d}(\mathrm{t})$ & $\begin{array}{c}150.0 \\
\sim 800.0\end{array}$ & - & - \\
\hline
\end{tabular}

$(1.0 \mathrm{t} \fallingdotseq 9.8 \mathrm{kN})$

表一7 解析モデル

\begin{tabular}{l|c|c|c|c|c|c}
\hline & \multicolumn{2}{|c|}{ MODEL-1 } & \multicolumn{2}{c|}{ MODEL-1 L } & \multicolumn{2}{c}{ MODEL-2 L } \\
\hline & $\mathrm{C} 10^{\prime}$ & $\mathrm{C} 10$ & $\mathrm{C} 10^{\prime}$ & $\mathrm{C} 10$ & $\mathrm{C} 10^{\prime}$ & $\mathrm{C} 10$ \\
\hline KIND OF & $\begin{array}{c}\text { AXIAL } \\
\text { CABLE }\end{array}$ & \multicolumn{2}{|c|}{ LINKING CABLE } \\
\hline TENSION (t) & 400.0 & 500.0 & 400.0 & 500.0 & 266.0 & 327.0 \\
\hline $\begin{array}{l}\text { CIRCULAR } \\
\text { FREQ. }(\mathrm{rad} / \mathrm{s})\end{array}$ & - & - & 2.9622 & 2.9895 & 2.4156 & 2.4176 \\
\hline
\end{tabular}

$(1.0 \mathrm{t} \fallingdotseq 9.8 \mathrm{kN})$

実橋設計例の諸元は 表一6 に示すようであり，解析モ デルは表一7 に示すように, MODEL-1, MODEL-1 L および MODEL-2 L の 3 ケースを考える. すなわち， MODEL-1 は従来の解析に対応して全段のケーブルを 単なる軸方向力部材として取り扱ったもの, MODEL$1 \mathrm{~L}$ は 10 段目の 4 本のケーブルのみを鎖状ケーブル部 材として取り扱ったものである.さらに, MODEL-2 L は，10 段目の 4 本のケーブルの弦としての 固有円振動 数が MODEL-1 の最低次のものである $\omega_{I}$ に近接する ように，プレストレスを含む完成時張力を調整したもの である.

固有振動解析は, 完成死荷重時の静的な平衡状態での 有限変位理論に基づく接線剛性行列によって線形化され る運動方程式に対して行い, 固有值問題の解法として は, Sturm Sequence 法 ${ }^{18)}$ を適用する.ささらに, 動的応 答解析は，完成死荷重時の接線剛性行列を常に用いる線 形化解析，および，各時間ステップにおいて文献 13) の 推定割線剛性行列を用いる非線形解析の両者の解析を直 接積分法によって行い, 常微分方程式の解法としては,

Newmark $\rho \beta$ 法 ${ }^{19}$ ) (加速係数 $\beta=0.25$, 時 間間隔 $\Delta t=0.06 \mathrm{~s}$ ）を適用する. なお，数值 計算における各段のケーブルの自重の処理, 無応力長の算定法, および, 主桁, 主塔の無 応力形状の算定法は, 前々章のものと同様で ある.

図一13〜15 および，表一8，9 が解析結果 を示すむのである.

まず, 表一8 が, 各解析モデルの固有円振 


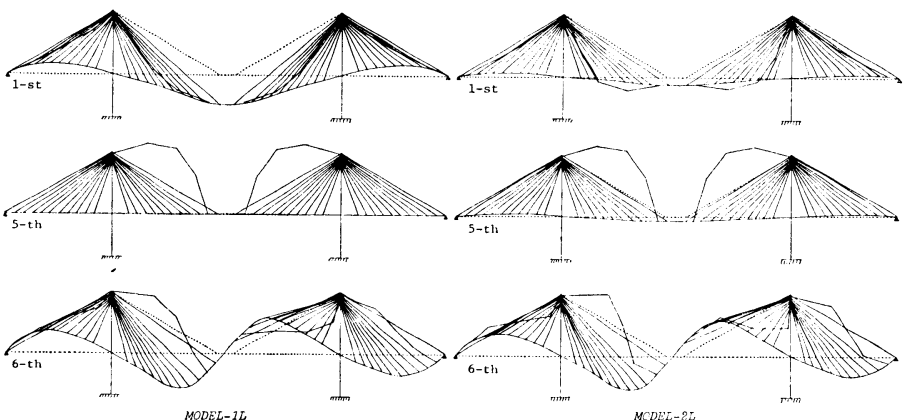

図一13 主桁の振動成分の卓越する固有振動モード
值によって算定される L-20 相当設計荷 重列の共振車頭間隔 $l$ の值が, 十分に実 現性のある走行状態に対応するものであ ることがわかる.

表一9 が，各解析モデルに対する，図 一12 に同時に示した各着目点の鉛直方 向変位, 曲げモーメント, 張力の静的 な場合の応答值，および，動的増幅率 (DAF)を表わすものである.図一14 は， 走行時の応答-時間曲線の例として, 着 目点 D 2, D 3 における鉛直方向変位の 応答-時間曲線を示すものである.これらの図表からは， MODEL-1 と MODEL-1 L とにほとんど差異はみら れないが，MODEL-2 L の場合に，定義した要因によ るシステムダンピングの効果が大きく，主桁の鉛直方向 変位のみならず, 曲げモーメント, および，ケーブルの 張力の動的増幅率がかなり低減されていることがわか る. 特に，主桁の中央点である着目点 D2 の鉛直方向変

表一9 各解析モテルの動的增幅率

\begin{tabular}{|c|c|c|c|c|c|c|}
\hline & $\begin{array}{c}\text { MODEL } \\
-1\end{array}$ & $\begin{array}{c}\text { MODEL } \\
-1 \mathrm{~L}\end{array}$ & \multicolumn{2}{|c|}{ MODEL-2 L } \\
\hline & & & \multicolumn{3}{|c|}{ Linearized Analysis } & Non-Li. \\
\hline \multirow{6}{*}{$\begin{array}{l}\text { Displ. } \\
\text { (m) }\end{array}$} & \multirow{2}{*}{ D 1} & Static & \multicolumn{3}{|c|}{-0.0611} & -0.0614 \\
\hline & & (DAF) & 1.121 & 1.132 & 1.091 & 1.106 \\
\hline & \multirow{2}{*}{ D 2} & Static & \multicolumn{3}{|c|}{0.1874} & 0.1879 \\
\hline & & (DAF) & 1.081 & 1.084 & 1.049 & 1.065 \\
\hline & \multirow{2}{*}{ D 3} & Static & \multicolumn{3}{|c|}{0.0904} & 0.0907 \\
\hline & & (DAF) & - & 1.204 & 2.562 & 2.192 \\
\hline \multirow{6}{*}{$\begin{array}{l}\text { Moment } \\
(\mathrm{t} \cdot \mathrm{m})\end{array}$} & \multirow{2}{*}{ M 1} & Static & \multicolumn{3}{|c|}{-2497.4} & -2507.2 \\
\hline & & (DAF) & 1.146 & 1.144 & 1.104 & 1.127 \\
\hline & \multirow{2}{*}{ M2 } & Static & \multicolumn{3}{|c|}{-1494.2} & -1492.6 \\
\hline & & $(\mathrm{DAF})$ & 1.025 & 1.018 & 1.017 & 1.016 \\
\hline & \multirow{2}{*}{ M 3} & Static & \multicolumn{3}{|c|}{2321.8} & 2331.6 \\
\hline & & (DAF) & 1.024 & 1.032 & 1.027 & 1.040 \\
\hline \multirow{12}{*}{$\begin{array}{c}\text { Tension } \\
(t)\end{array}$} & \multirow{2}{*}{$\mathrm{C} 06^{\prime}$} & Static & \multicolumn{3}{|c|}{34.582} & 34.594 \\
\hline & & (DAF) & 1.049 & 1.064 & 1.059 & 1.061 \\
\hline & \multirow{2}{*}{$\mathrm{C} 10^{\prime}$} & Static & \multicolumn{3}{|c|}{107.142} & 107.421 \\
\hline & & (DAF) & 1.107 & 1.110 & 1.072 & 1.084 \\
\hline & \multirow{2}{*}{$\mathrm{C} 11^{\prime}$} & Static & \multicolumn{3}{|c|}{125.664} & 125.983 \\
\hline & & (DAF) & 1.108 & 1.113 & 1.075 & 1.088 \\
\hline & \multirow{2}{*}{$\mathrm{C} 06$} & Static & \multicolumn{3}{|c|}{57.594} & 57.642 \\
\hline & & (DAF) & 1.079 & 1.074 & 1.054 & 1.058 \\
\hline & \multirow{2}{*}{$\mathrm{C} 10$} & Static & \multicolumn{3}{|c|}{47.362} & 47.466 \\
\hline & & (DAF) & 1.083 & 1.096 & 1.066 & 1.087 \\
\hline & \multirow{2}{*}{ C 11} & Static & \multicolumn{3}{|c|}{41.011} & 41.114 \\
\hline & & (DAF) & 1.094 & 1.106 & 1.070 & 1.097 \\
\hline
\end{tabular}

$(1.0 \mathrm{t} \fallingdotseq 9.8 \mathrm{kN})$

動数を表わすものである. この表には，参考のために， 1 次と 5 次のモードに対応する振動による beating 現象 の周期も付記してある. また, 図一13 が, MODEL-1 L, MODEL-2 L の 1, 5, 6 次の固有振動モード (2, 3, 4 次はケーブルのみが個々に横振動する モードである) を示すものである. これらの図表からは, MODEL-2 L の場合に, 部分構造系として主桁の振動と内部共振を起 こすケーブルが 4 本であることから，5 種の固有円振動 数 $\omega_{1} \sim \omega_{5}$ が近接するが，ケーブルが逆位相で連成し， 主桁の振動成分が卓越するモードは, $\omega_{1}$ と $\omega_{5}$ に対応す る 1 次と 5 次の 2 種の固有振動モードであることがわか る. さらに, MODEL-1 の最低次の固有円振動数 $\omega_{I}$ の
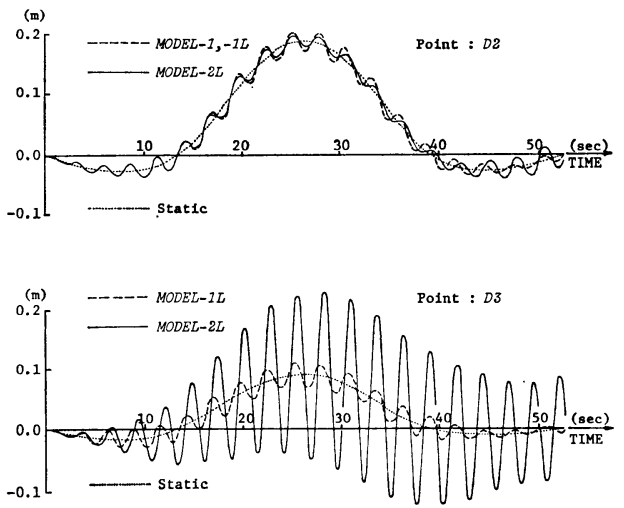

図-14 走行時の応答-時間曲線の例 

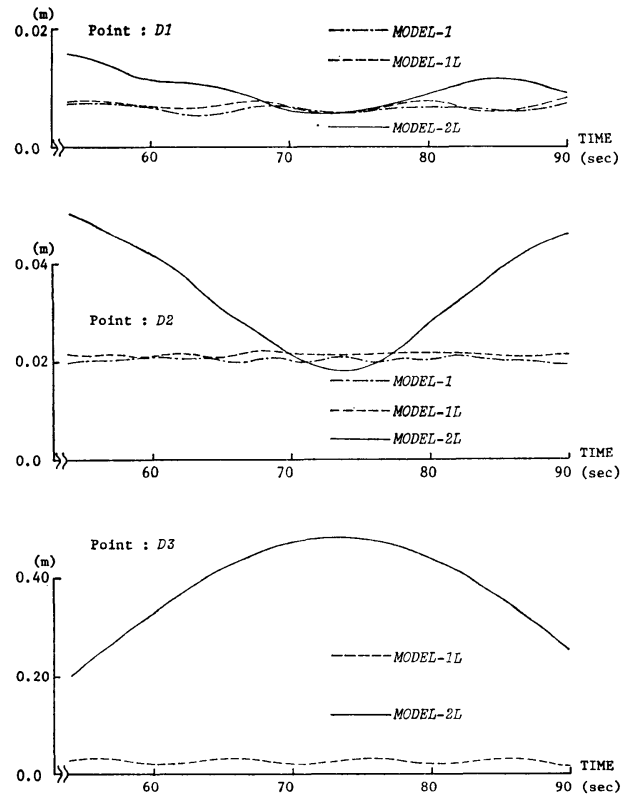

図一15 残留自由振動時の鉛直方向変位の 両振幅の時間曲線

位については, 動的応答の最大值が自由振動項の beat. ing 現象の $1 / 2$ 周期の時刻付近で生じたことから, 衝撃 係数に換算すれば, 約 $60 \%$ 程度に低減されていること がわかる. また, 非線形解析によって得られた值は, 線 形化解析によるものと比較して, 静的な值にはほとんど 差異がないにもかかわらず, システムダンピングの効果 が減じる傾向にあり，10 段目の ケーブルの 張力の増加 による横振動性状の変化がもたらす非線形性を無視でき ないことがわかる. すなわち, この問題が, 動的な場合 に特有の非線形問題の一つであることがわかる.

さらに, 図一15 が, 走行終了後の残留自由振動時の 着目点 D 1, D 2, D 3 における鉛直方向変位の両振幅の 時間曲線を示すものである. この図からは, MODEL$2 \mathrm{~L}$ の場合に, beating 現象の $1 / 2$ 周期の時刻までに振 幅の急激な変化がみられ, 主析の振動振幅は, 構造減衰 との相互作用から定義した要因によるシステムダンピン グによって急速に低減されることがわかる．ただし，荷 重列の通過直後における MODEL-2 L の場合の振幅が 他に比較して大きいのは, 残留自由振動の初期条件の差 異によるものであり，その大小は問題でない.

なお, 以上の解析結果においては, ケーブルの振動振 幅が beating 現象によって逆に増大する傾向がみられて おり, 張力が減少していることからは直接的に有害な挙 動とはいえないが, 設計時に配慮すべき問題であると思 われる.

\section{6. 結言}

本文は, 斜張橋のシステムダンピングの支配的な一要 因を新たに定義し, 定義の妥当性の検討を行い, さらに は，若干の設計資料を得ることを試みたものである．種 種の数値計算結果, 実橋試験結果, および, マルチケー ブル型式の長大斜張橋の動的応答解析結果からは, 次の ようなことがいえる.

（1）部分構造系としてのケーブルと主桁の振動の内 部共振によって生じる, おのおのの相似な振動成分が異 なる比率で連成し, 固有円振動数が近接した, 2 種の固 有振動モードに対応する自由振動項の beating 現象が, 斜張橋のシステムダンピングの支配的な一要因である.

（2）マルチケーブル型式斜張橋の特定のケーブルの みの完成時張力を調整した場合においても, 定義した要 因によるシステムダンピングは, 主桁の鉛直方向変位の みならず, 曲げモーメント, および, ケーブルの張力の 平滑走行荷重による衝撃係数をかなり低減する効果を与. えることが可能である.

（3）同様の場合の走行終了後の残留自由振動時にお いても, 定義した要因によるシステムダンピングは, 構 造減衰も作用することによって, 高い減衰性を与えるこ とが可能である.

（4）これらのような効果はケーブルを鎖状ケーブル として取り扱うことによって容易に解析されるが, 張力 の変動による横振動性状の変化に伴う動的な場合に特有 の非線形問題の一つであり, より正確な把握のために は, 幾何学的非線形性を考慮した動的応答解析も必要で ある・

したがって, 長大斜張橋の動的応答特性を検討する立 場, および, 経済的な設計を行う立場からも, 定義した 要因によるシステムダンピングの効果は，考慮に值する ものであると思われる. また, 本文では, 動的外力とし て走行荷重のみを考えたが，完成時および架設途中にお ける限定振動（風琴振動）に対する効果については, 今 後の研究課題であると思われる.

最後に, 本研究における, 本州四国連絡橋公団・成井 信氏の多大のご尽力, および, 当時, 卒研生であった大 阪大学大学院・藤原 要君の多大のご苦労に対し, 心よ り謝意を表する.

\section{参考文 献}

1) Leonhardt, F., et al. : Cable-stayed Bridges, Report on Latest Development, Canadian St. Eng. Conf., 1970.

2) Leonhardt, F., et al. : Vergleiche zwischen Hängebrucken und Schrägseilbrücken für Spannweiten über $600 \mathrm{~m}$, Abhandlungen 32-I, IVBH, 1972. 
3）大阪湾岸線技術委員会編：昭和 50 年度大阪湾岸線（III 期）調查報告書，阪神高速道路公団，1976.

4）土木学会編 : 昭和 54 年度本州四国連絡橋鋼上部構造に関 する調查研究報告書 (別冊 3 - 櫃石島, 岩黒島斜張橋に 関する検討), 本州四国連絡橋公団, 1980 .

5) Leonhardt, F., et al. : Cable-Stayed Bridges, IABSE SURVEYS, S-13/80, 1980.

6) Havemann, H.K.: Spannungs-und Schwingungsmessungen an der Brücke über die Norderelbe im Zuge der Bundesautobahn Südliche Umgehung Hamburg, Stahlbau 33, 1964.

7) Leonhardt, F., et al. : Modellversuche für die Schrägkabelbrücken Zárate-Brazo Largo über den Rio Paraná (Argentinien), Bauingenieur 54, 1979.

8) Baglietto, E., et al. : Mathematical and Structural Models of Zárate-Brazo Largo Bridges, ISMES-Bericht No. 85, Bergamo (Italien), 1976.

9) Leonhardt, F., et al. : Die Spannbeton-Schrägkabelbrücke über den Columbia River Zwischen Pasco und Kennewick im Staat Washington (USA), Beton und Stahlbetonbau, Heft 2, 3 und 4, 1980.

10）小松定夫・川谷充郎：斜張橋の自動車走行による動的応 答と衝撃係数に関する研究, 土木学会論文報告集, No. 275,1978 .

11）高久達将・宮村隆夫 - 原 茂樹 - 藤沢伸光 : 通信専用斜 張橋の設計と施工，日本鋼管技報，No. 91,1981 .
12）樋上琇一・佐々木 敏：中規模斜張橋の構造減衰と耐風 安定性, 土木学会第 37 回年次学術講演会講演概要集, 1982.

13）前田幸雄・林 正・前田研一：幾何学的非線形性を考虑 した平面骨組構造物の動的応答解析法, 土木学会論文報 告集, No. 249, 1976.

14) Maeda, Y., M. Hayashi and K. Maeda : Non-Linear Vibration Analysis of Plane Framed Structures by Finite Element Method, Proc. of the 24th Japan National Congress for Applied Mechanics, 1974.

15）前田幸雄・林 正・前田研一：斜張橋の設計における非 線形問題, 第 24 回構造工学シンポジウム論文集, 1978 .

16）梅沢宣男・前田研一 - 松橋 省：2 径間非連続析斜張橋 の振動特性, 土木学会 第 35 回年次学術講演会講演概要 集, 1980 .

17）たとえば, Jacobsen, L.S. and R.S. Ayre : Engineering Vibrations with Application to Structures and Machinery, McGraw-Hill Book Co., Inc., 1958 (後藤・金多 訳 : 振動工学, 丸善図書株式会社, 1961).

18) Gupta, K.K. : Eigenproblem Solution by a Combined Sturm Sequence and Inverse Iteration Technique, Int. J. for Numerical Meth. in Engineering, Vol. 7, 1973.

19) Newmark, N.M.: A Method of Computation for Structural Dynamics, Proc. of ASCE, EM 3, 1959.

(1982.3.13 . 受付) 